Article

\title{
Influence of Glass Phase in Silver Paste on Metallized Contact Resistance between Rear Silver and Aluminum Electrodes of Crystalline Silicon PERC Cells
}

\author{
Jiefeng Zhang $\mathbb{D}$, Hui Li, Hua Tong *, Shenghu Xiong, Yunxia Yang, Xiao Yuan, Hongbo Li and \\ Cui Liu
}

Key Laboratory for Ultrafine Materials of Ministry of Education, School of Materials Science and Engineering, East China University of Science and Technology, Shanghai 200237, China; Y30160498@mail.ecust.edu.cn (J.Z.); Y45170055@mail.ecust.edu.cn (H.L.); 010140143@mail.ecust.edu.cn (S.X.); yangyunxia@ecust.edu.cn (Y.Y.); yuanxiao@ecust.edu.cn (X.Y.); lihongbo@ecust.edu.cn (H.L.); liucui@ecust.edu.cn (C.L.)

* Correspondence: tonghua@ecust.edu.cn; Tel.: +86-216-425-3395

Received: 27 January 2019; Accepted: 26 February 2019; Published: 2 March 2019

\begin{abstract}
In the back-side metallization process of the passivated emitter and rear cell (PERC), the contact between the $\mathrm{Ag}$ rear electrode and $\mathrm{Al}$ rear electrode is an important factor for cell efficiency. In this paper, we report on the effect of Ag paste containing two types of oxide glass frit, V-B-Te and $\mathrm{Pb}-\mathrm{B}-\mathrm{Si}$, on the $\mathrm{Ag} / \mathrm{Al}$ contact, owing to their remarkable contrast with regard to the $\mathrm{Ag} / \mathrm{Al}$ contact resistance. By combining the observation of the $\mathrm{Ag} / \mathrm{Al}$ interface structure with the investigation on the interaction between glass and $\mathrm{Al}$, glass transition temperature, and the distribution of glass phase in the Ag electrode, the influence of the glass phase on the contact resistance between rear $\mathrm{Ag}$ and $\mathrm{Al}$ electrodes was clearly elucidated.
\end{abstract}

Keywords: glass phase; $\mathrm{Ag}$ paste; $\mathrm{Ag} / \mathrm{Al}$ contact; PERC

\section{Introduction}

A passivated emitter and rear cell (PERC) concept with rear surface passivation and local aluminum (Al) rear contacts was first proposed in 1989 [1]. In recent years, PERC solar cells have undergone rapid development and become one of the most important high-efficiency photovoltaic products. Different from the conventional crystalline silicon (c-Si) solar cells, PERC solar cells demand that the rear $\mathrm{SiN}_{\mathrm{x}} / \mathrm{Al}_{2} \mathrm{O}_{3}$ passivation layer not be corroded by silver (Ag) paste during the sintering process. However, meeting this requirement results in the emergence of other issues. Specifically, the much greater contact resistance between rear Ag and $\mathrm{Al}$ electrodes often becomes a critical problem, impairing cell efficiency $[2,3]$.

In general, the metallization Ag paste for c-Si cells is composed of Ag powder, glass frit, and an organic vehicle. The glass frit serves as a solder to bond the fired Ag electrode to the cells, and thus it influences the contact resistance between them. On the front-side of the cells, the Ag/Si contact $\mathrm{Ag}$ paste is used, and the firing of this $\mathrm{Ag}$ paste results in etching of the $\mathrm{SiN}_{\mathrm{x}}$ passivation layer and formation of $\mathrm{Ag} / \mathrm{Si}$ ohmic contact by a glass-phase medium [4,5]. In this case, the key role of the glass frit involved and the relevant mechanism of the current transmission through the $\mathrm{Ag} / \mathrm{Si}$ contact have been extensively studied [6-8]. However, in the rear-side metallization of PERC solar cells, the $\mathrm{Ag} / \mathrm{Si}$ non-contact $\mathrm{Ag}$ paste is employed to form a Si/Al/Ag interconnection for current transmission $[2,3]$. So far, little attention has been paid to the influence of the glass frit in Ag paste on the contact resistance 
between the $\mathrm{Ag}$ and $\mathrm{Al}$ electrode. According to our investigation, this influence would be quite marked in terms of the glass frit composition, and thus produces an important effect on the cell efficiency.

The PbO-containing glass frit has been widely used in commercial Ag paste for c-Si solar cells due to its desired property of forming an $\mathrm{Ag} / \mathrm{Si}$ contact [4,5]. Generally, the lead glass frit used in the front-side Ag paste demonstrates good performance with regard to corroding the $\mathrm{SiN}_{\mathrm{x}}$ passivation layer. However, the glass frit used in rear Ag paste for PERC solar cells is expected to not corrode the $\mathrm{SiN}_{\mathrm{x}}$ passivation layer. Although up to now, the PbO-containing glass frit has been employed in the majority of rear Ag pastes, there is a potential risk of degrading the cell efficiency due to the corrosion effect of $\mathrm{PbO}$ on the $\mathrm{SiN}_{\mathrm{x}}$ passivation layer. Accordingly, we investigated the application of boro-vanadate glass frit in the rear Ag paste for PERC solar cells.

Herein, we present an investigation on the effect of the glass phase on the formation of the $\mathrm{Ag} / \mathrm{Al}$ contact in rear Ag paste metallization on PERC solar cells. In this article, the $\mathrm{Ag} / \mathrm{Al}$ contact resistance is discussed with respect to the dependence of the contact interface structure on the glass frit composition.

\section{Experiment}

\subsection{Materials}

The purity of the raw materials used in these experiments were: Vanadic oxide $\left(\mathrm{V}_{2} \mathrm{O}_{5}, 99.5 \%\right.$, Sinopharm, Shanghai, China), boracic acid $\left(\mathrm{H}_{3} \mathrm{BO}_{3}, 99.5 \%\right.$, Sinopharm, Shanghai, China), tellurium oxide ( $\mathrm{TeO}_{2}, 99.5 \%$, Sinopharm, Shanghai, China), lead oxide ( $\mathrm{PbO}, 99.5 \%$, Sinopharm, Shanghai, China) and silicon dioxide $\left(\mathrm{SiO}_{2}, 99.5 \%\right.$, Sinopharm, Shanghai, China). The Ag powder, with a flaky shape and thickness of around 50-200 nanometers was purchased from Suzhou Smart Surface Material Company (Suzhou, China) Al paste was purchased from Guangzhou Ruxing Technology Development Company (Guangzhou, China).

\subsection{Synthesis of Glass Frit Powder}

The melt-quenching method was used to prepare the glass frit used in this work. Uniform stoichiometric mixtures of oxide powders were mixed in an agate mortar. After tempering at $1300{ }^{\circ} \mathrm{C}$ for $1 \mathrm{~h}$ in an aluminum crucible, the sample was cooled rapidly to room temperature by removing the aluminum crucible from the furnace and pouring the melt into de-ionized water. After grinding in a planetary mill for $3 \mathrm{~h}$ at $660 \mathrm{rpm}$, two types of glass frit, as shown in Table 1, with $\mathrm{D}_{50}$ of around $2.26 \mu \mathrm{m}$ were obtained.

Table 1. Composition of the glass frit.

\begin{tabular}{cccccc}
\hline \multirow{2}{*}{ Glass Frit } & \multicolumn{5}{c}{ Composition (mol\%) } \\
\cline { 2 - 6 } & $\mathrm{V}_{\mathbf{2}} \mathbf{O}_{\mathbf{5}}$ & $\mathrm{TeO}_{\mathbf{2}}$ & $\mathbf{H}_{\mathbf{3}} \mathbf{B O}_{3}$ & $\mathbf{P b O}$ & $\mathbf{S i O}_{\mathbf{2}}$ \\
\hline $\mathrm{G}-1$ & 25 & 50 & 25 & - & - \\
$\mathrm{G}-2$ & - & - & 20 & 40 & 40 \\
\hline
\end{tabular}

\subsection{Preparation of $A g$ Paste and Metallization}

Ag powder, glass frit, and organic medium in the ratio of 60.8:1.2:38 $\mathrm{wt} \%$ were mixed using a three-roll mill. Two kinds of Ag paste (here denoted as P-1 and P-2) which respectively contained G-1 and G-2 glass frit were synthesized.

The pastes were screen-printed onto $\mathrm{SiN}_{\mathrm{x}} / \mathrm{Al}_{2} \mathrm{O}_{3}$ passivated mono-crystalline wafer using a two-step printing process. Firstly, Ag paste was screen-printed into a discontinuous line pattern with a width of $3 \mathrm{~mm}$, height of around $4 \mu \mathrm{m}$, and total length of $35 \mathrm{~mm}$ on a mono-crystalline wafer. Secondly, Al paste was screen-printed into 5 x 5 square pads to interconnect the pre-printed Ag paste. After drying in a belt furnace at $200{ }^{\circ} \mathrm{C}$ for $1 \mathrm{~min}$ to volatilize the organic phase, the samples were then 
sintered in an infrared furnace in which the $\mathrm{Si}$ wafer was in contact with the thermocouple at a peak temperature of $700{ }^{\circ} \mathrm{C}$ for $6 \mathrm{~s}$ to form the $\mathrm{Ag} / \mathrm{Al}$ contact. The contact pattern between the $\mathrm{Ag}$ and $\mathrm{Al}$ electrode is shown in Figure 1.

To test the effect of Ag paste composition on finished devices, PERC solar cells were fabricated using the following sequence. Firstly, the wafer went through cleaning using deionized water, texturing by $\mathrm{NaOH}$ aqueous solution, diffusion using a $\mathrm{POCl}_{3}$ source, edge etching, $\mathrm{Al}_{2} \mathrm{O}_{3}$ passivation layer deposition by atomic layer deposition (ALD), $\mathrm{SiN}_{\mathrm{x}}$ antireflection coating by plasma-enhanced chemical vapor deposition (PECVD), and rear laser contact opening. Then, prepared Ag rear paste was deposited on the back surface of the wafer by screen printing. For all the $\mathrm{Si}$ wafers, the same commercial $\mathrm{Al}$ rear paste and front-side $\mathrm{Ag}$ paste were screen-printed to form a rear $\mathrm{Ag} / \mathrm{Al}$ contact and a front $\mathrm{Ag} / \mathrm{Si}$ contact. Finally, the Si wafer was fired in a nine-temperature-region belt furnace (Despatch, Miami, FL, USA) at a set peak temperature of $875^{\circ} \mathrm{C}$ and a belt speed of $600 \mathrm{~cm} / \mathrm{min}$.

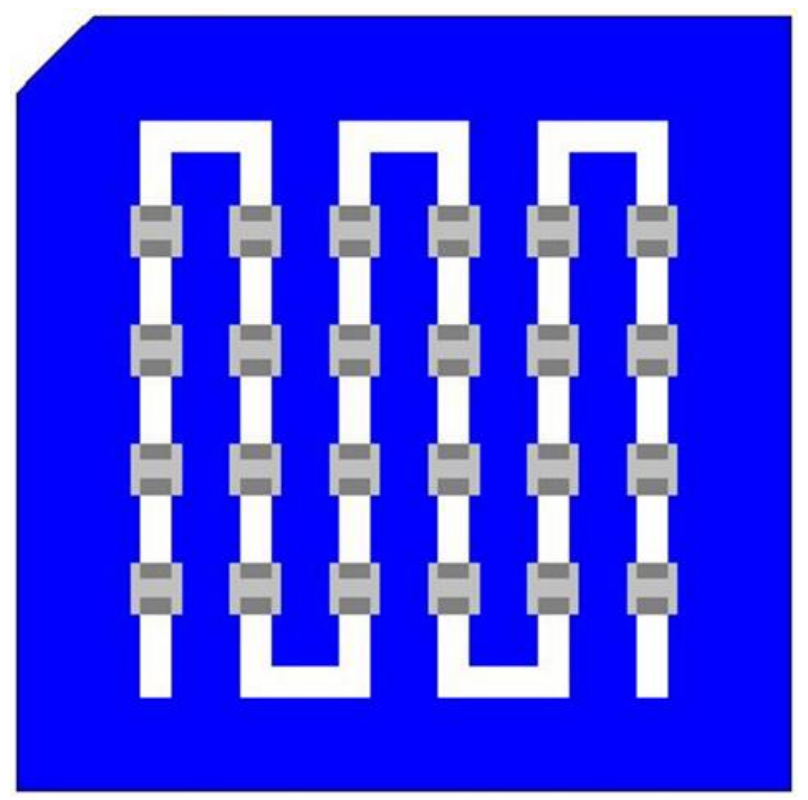

Figure 1. The contact pattern between the $\mathrm{Ag}$ and $\mathrm{Al}$ electrode. Ag paste was screen-printed into a discontinuous line on the $\mathrm{SiN}_{\mathrm{x}} / \mathrm{Al}_{2} \mathrm{O}_{3}$ passivated $\mathrm{Si}$ wafer, and then $\mathrm{Al}$ paste was printed into $5 \times 5$ square pads to interconnect the Ag paste. In order to magnify the contact effect, this model contains 48 $\mathrm{Ag} / \mathrm{Al}$ joints with an overlap of 4.5 square millimeters for each contact.

\subsection{Measurements}

The $\mathrm{Ag} / \mathrm{Al}$ contact resistance, $\mathrm{R}$, was measured by a digital micro-ohmmeter (PC9A, Agilent, PaloAlto, CA, USA). The Differential Scanning Calorimeter (DSC) curve of the glass frit was recorded using a DSC instrument (Q20, TA, Wilmington, DE, USA) in air and a heating rate of $10{ }^{\circ} \mathrm{C} / \mathrm{min}$. The surface morphology of the Ag electrode and the interface microstructure between the Ag electrode and $\mathrm{Al}$ electrode were observed by a Field-Emission Scanning Electron Microscope (FE-SEM, Hitachi, S-4800, Tokyo, Japan) equipped with energy-dispersive X-ray spectrometry (EDS, Tokyo, Japan). The electrical parameters of PERC solar cells were measured on a photovoltaic I-V test system under AM1.5 spectrum at the temperature of $25^{\circ} \mathrm{C}$.

\section{Results and Discussion}

In the currently exemplified Ag paste for rear-side metallization of c-Si PERC solar cells, the content of the glass frit is $1.2 \%$ of the total mass, while the Ag powder accounts for nearly $60 \%$. For comparison, two Ag pastes were prepared using different glass frits labeled as G-1 and G-2, respectively. Both the two glass frits can meet the requirement of the rear Ag paste for PERC 
solar cells, making a firm and non-corrosive interconnection between the fired Ag electrode and the rear $\mathrm{SiN}_{\mathrm{x}} / \mathrm{Al}_{2} \mathrm{O}_{3}$ passivation layer, see Supporting Information Figure S1. When used with PERC solar cells, the two pastes resulted in significantly different performances. Table 2 presents the I-V cell characterization results. It is shown that the two cells had similar open circuit voltages $\left(\mathrm{V}_{\mathrm{oc}}\right)$ and short circuit currents $\left(\mathrm{I}_{\mathrm{sc}}\right)$ but differed remarkably in Fill Factor $(\mathrm{FF})$. Clearly, the lower FF gained with the G-1 glass frit was attributed to the greater series resistance $\left(R_{S}\right)$, which was $98.68 \%$ larger than when the G-2 glass frit was used. As a result, the cell efficiency with the G-1 glass frit had a 0.33 percentage point decrease compared to what was achieved with the G-2 glass frit.

Table 2. I-V cell characterization results.

\begin{tabular}{cccccc}
\hline Glass Frit & $\mathbf{V}_{\mathbf{o c}}(\mathbf{m V})$ & $\mathbf{I}_{\mathbf{s c}}(\mathbf{m A})$ & $\mathbf{R}_{\mathbf{s}}(\mathbf{m} \boldsymbol{\Omega})$ & $\mathbf{F F}(\mathbf{\%})$ & Efficiency (\%) \\
\hline G-1 & 664 & 9.72 & 3.02 & 79.48 & 20.96 \\
G-2 & 667 & 9.71 & 1.52 & 80.45 & 21.29 \\
\hline
\end{tabular}

To ascertain the reason for the difference in $\mathrm{R}_{\mathrm{S}}$ between the two cells, the line resistance of the fired $\mathrm{Ag}$ electrode and the contact resistance between the rear $\mathrm{Ag}$ and $\mathrm{Al}$ electrode were studied. The two $\mathrm{Ag}$ paste electrodes had almost the same line resistivity, see Supporting Information Figures S2 and S3, implying that the difference in $\mathrm{R}_{\mathrm{s}}$ between the two cells resulted from the difference in the contact resistance between the rear Ag and $\mathrm{Al}$ electrode. As presented in Figure 2, the Ag/ $\mathrm{Al}$ electrode contact resistance was tested to be $36 \Omega$ for P-1 paste and $2 \Omega$ for P-2 paste, respectively. This remarkable difference can be attributed to the significant influence of the glass frit on the $\mathrm{Ag}$ and $\mathrm{Al}$ paste metallization because P-1 and P-2 paste differed only in the glass composition.

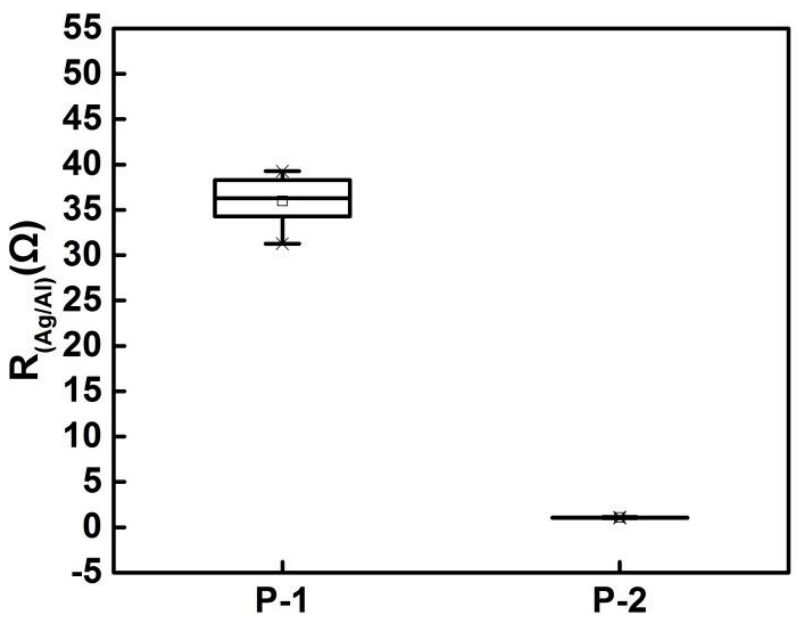

Figure 2. The chart of $\mathrm{Ag} / \mathrm{Al}$ electrode contact resistance.

The $\mathrm{Ag} / \mathrm{Al}$ electrode contact interface was observed by using a FE-SEM. Figure 3a1,a2 show $\mathrm{Ag} / \mathrm{Al}$ electrode cross-sectional images between P-1 paste and Al paste. The surface of $\mathrm{Al}$ particles was relativity smooth, as shown in Figure 3a1, and the FE-SEM image at higher magnification shows that there was an inter-miscible zone between the Ag electrode and the Al electrode, see Figure 3a2. We observed different results when P-2 paste was printed and sintered with Al paste, see Figure 3b1,b2. The surface of $\mathrm{Al}$ particles was quite rough, as shown in Figure 3b1. In addition, from the higher magnification FE-SEM image, shown in Figure 3b2, we observed that no inter-miscible zone formed at the $\mathrm{Ag} / \mathrm{Al}$ electrode contact interface and the surface of $\mathrm{Al}$ particles was covered with some large aspect ratio metal precipitate films which resulted from the inter-diffusion between $\mathrm{Ag}$ and $\mathrm{Al}$ during the sintering process $[9,10]$. Our previous research revealed that the inter-miscible zone formed between the Ag electrode and $\mathrm{Al}$ electrode was glass layer dissolved metal particles [11]. Therefore, 
the high resistance and non-conductive glass layer could hinder the current transmission between the $\mathrm{Ag}$ electrode and $\mathrm{Al}$ electrode, causing high $\mathrm{Ag} / \mathrm{Al}$ contact resistance.

The above results indicate that a significant difference in the $\mathrm{Ag} / \mathrm{Al}$ contact resistance is caused by the different $\mathrm{Ag} / \mathrm{Al}$ contact interfaces. Therefore, the different $\mathrm{Ag}$ pastes, especially, the contained glass frit, have a significant effect on the $\mathrm{Ag} / \mathrm{Al}$ contact resistance and interfacial morphology.
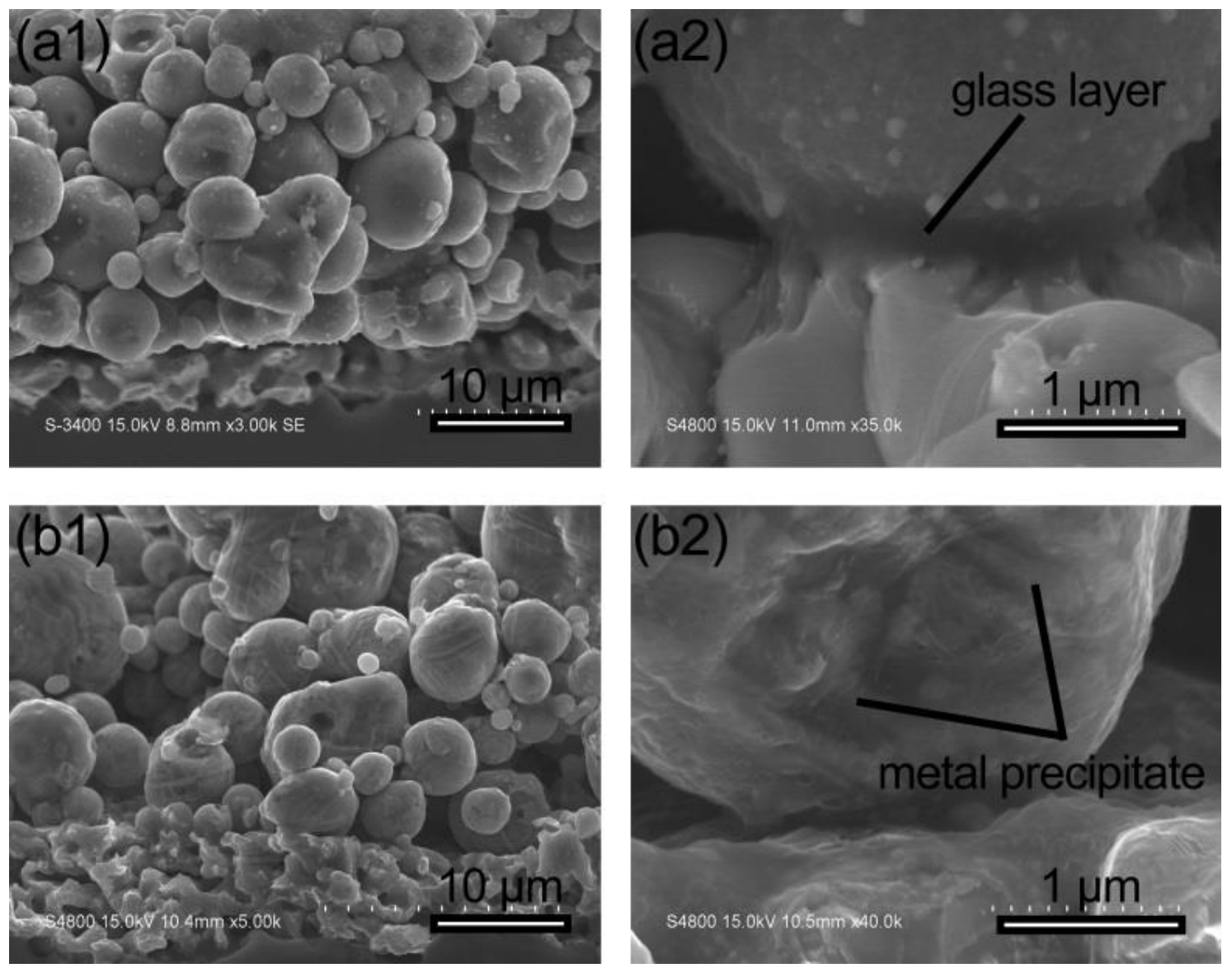

Figure 3. FE-SEM images showing contact interface between Al electrode and Ag electrode. (a1) and (a2): Low and high magnification images for P-1 paste. (b1) and (b2): Low and high magnification images for P-2 paste.

To reveal the interaction between glass frit and $\mathrm{Al}$ in co-sintering, we investigated the reaction of glass with $\mathrm{Al}$ by firing a glass frit coated in $\mathrm{Al}$ foil in an open electric furnace at $700{ }^{\circ} \mathrm{C}$ for $1 \mathrm{~min}$, as shown in Figure 4. The interaction between G-1 glass frit and $\mathrm{Al}$ was evident, and $\mathrm{Al}$ foil changed into a quasi-transparent thin film after sintering, see Figure 4a. However, different results occurred when using the G-2 glass frit and results showed that the G-2 glass did not react with Al, see Figure $4 \mathrm{~b}$. The different reaction degree between glass frit and $\mathrm{Al}$ foil indicated that the glass frit in Ag paste leads to a different $\mathrm{Ag} / \mathrm{Al}$ electrode contact interface by reacting with $\mathrm{Al}$ paste during sintering metallization, thus causing a remarkable difference in the contact resistance. 

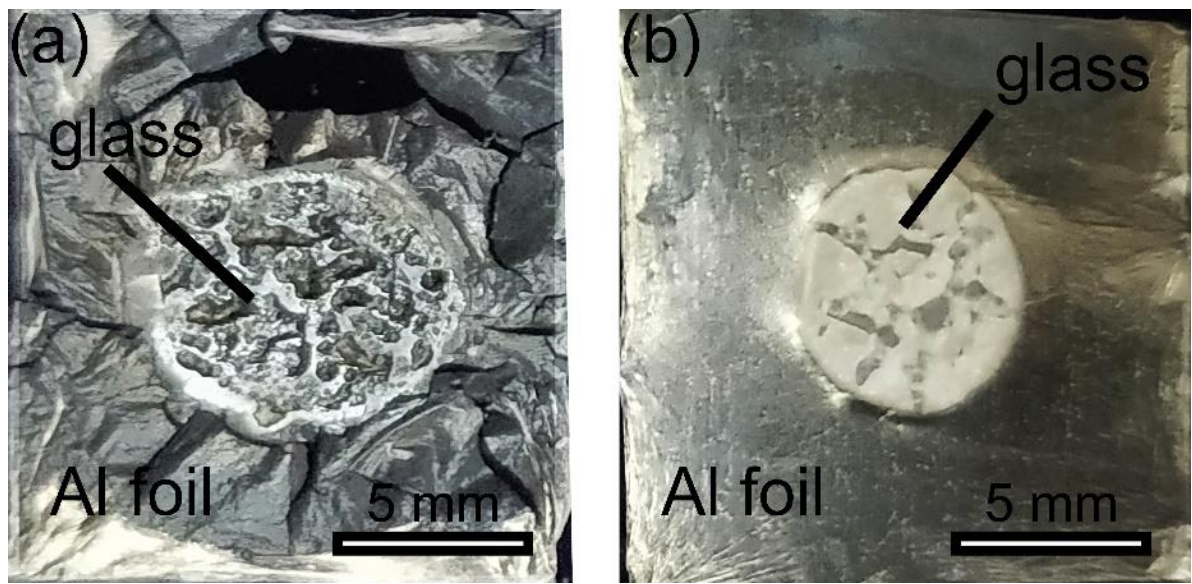

Figure 4. Photographs showing the interaction of glass with $\mathrm{Al}$ by firing a glass frit coated in $\mathrm{Al}$ foil in an open electric furnace at $700{ }^{\circ} \mathrm{C}$ for $1 \mathrm{~min}$. (a) G-1 glass frit; (b) G-2 glass frit.

To further reveal the interaction between glass and $\mathrm{Al}$, the mixture of glass frit and $\mathrm{Al}$ powder was heated at $700{ }^{\circ} \mathrm{C}$ for $1 \mathrm{~min}$ on the $\mathrm{Si}$ wafer after mixing them in an agate mortar at the mass ratio of 1:1. Figure 5a shows a FE-SEM cross-sectional image obtained when using the G-1 glass frit. It is clearly seen that the molten glass phase is totally coated in the Al particles, forming a non-conductive layer. However, when using the G-2 glass, we observed that some areas of the Al particles were not coated with glass frit, see Figure $5 \mathrm{~b}$. Glass, as a non-conductive phase, can hinder the current transmission. Therefore, the glass layer coated on Al particles forms a barrier between the $\mathrm{Ag}$ electrode and $\mathrm{Al}$ electrode, obstructing the current transmission between $\mathrm{Ag}$ and $\mathrm{Al}$ and causing a high $\mathrm{Ag} / \mathrm{Al}$ contact resistance.
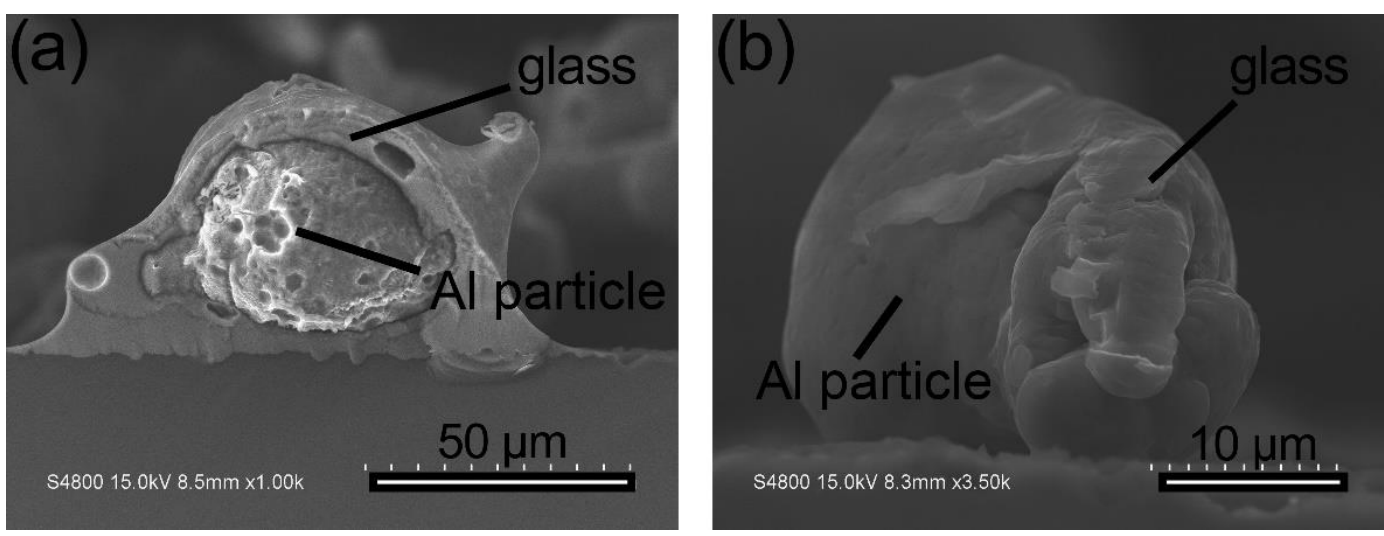

Figure 5. SEM images showing the interaction between glass and $\mathrm{Al}$ by heating the mixer of glass frit and $\mathrm{Al}$ powder at $700{ }^{\circ} \mathrm{C}$ for $1 \mathrm{~min}$. (a) G-1 glass frit; (b) G-2 glass frit.

Figure 6 shows the DSC curve of glass frit powder prepared by the traditional melting route. It was noticed that the glass transition temperatures $T_{g}$ of G-1 and G-2 glass frit powder are $259.89{ }^{\circ} \mathrm{C}$ and $513.31{ }^{\circ} \mathrm{C}$, respectively. The $\mathrm{T}_{\mathrm{g}}$ of glass frit plays an important role in the physical and electrical properties of thick-film Ag contacts [12]. For the contact between the front-side Ag electrode and $\mathrm{Si}$ emitter surface, increasing the current transmission path at the $\mathrm{Ag} / \mathrm{Si}$ interface is beneficial for achieving low $\mathrm{Ag} / \mathrm{Si}$ contact resistance and high cell efficiency. It was reported that the glass frit with low $\mathrm{T}_{\mathrm{g}}$ in front-side $\mathrm{Ag}$ paste flows easily during the sintering process, allowing the glass to react with Ag for a long time and, consequently, dissolves more Ag particles, resulting in a great number of Ag precipitates distributed on the Si emitter surface and improving the possibility of tunneling, eventually achieving a low $\mathrm{Ag} / \mathrm{Si}$ contact resistance and a high cell efficiency $[13,14]$. Many previous 
studies [12-14] focused on the effect of the $\mathrm{T}_{\mathrm{g}}$ of the glass frit on the $\mathrm{Ag} / \mathrm{Si}$ contact formation but ignored the $\mathrm{T}_{\mathrm{g}}$ of the glass frit on the $\mathrm{Ag} / \mathrm{Al}$ contact resistance. In general, for the contact between the rear $\mathrm{Ag}$ and $\mathrm{Al}$ electrodes, low $\mathrm{Ag} / \mathrm{Al}$ contact resistance is favorable to achieve low series resistance $\left(R_{s}\right)$ and high cell efficiency. In this study, we found that a glass frit with lower $T_{g}$ in the rear Ag paste easily flowed and wrapped $\mathrm{Al}$ particles during the sintering process, causing a non-conductive barrier between the $\mathrm{Ag}$ electrode and $\mathrm{Al}$ electrode and resulting in a higher $\mathrm{Ag} / \mathrm{Al}$ contact resistance.

The influence of the glass frit on $\mathrm{Ag} / \mathrm{Al}$ contact resistance was further investigated by using a field-emission scanning electron microscope, as shown in Figure 7. From the top SEM image, see Figure 7a, of the Ag electrode with P-1 paste, it was found that Ag precipitates with a diameter size of around $10 \mathrm{~nm}$ emerged and tended to be distributed in the grain boundaries. Some different results occurred in the case of using P-2 paste and no precipitates existed on the sintered Ag grain boundaries and surface of $\mathrm{Ag}$ grains, see Figure $7 \mathrm{~b}$. These Ag nanoparticles were formed from recrystallization of the Ag element, which was dissolved in the glass melt during the sintering of $\mathrm{Ag}$ paste. Accordingly, the location of Ag nanoparticles can mark the distribution of the glass phase. Basically, the lower the glass $T_{g}$, the earlier the glass starts to flow during the firing cycle [12]. Thus, in comparison with G-2 glass, the melt of G-1 glass frit had the larger distribution at the surface of the sintered electrode, causing a non-conductive glass layer on the Ag electrode. This non-conductive glass phase can hinder the current transmission between the Ag electrode and $\mathrm{Al}$ electrode and causes a high $\mathrm{Ag} / \mathrm{Al}$ contact resistance.

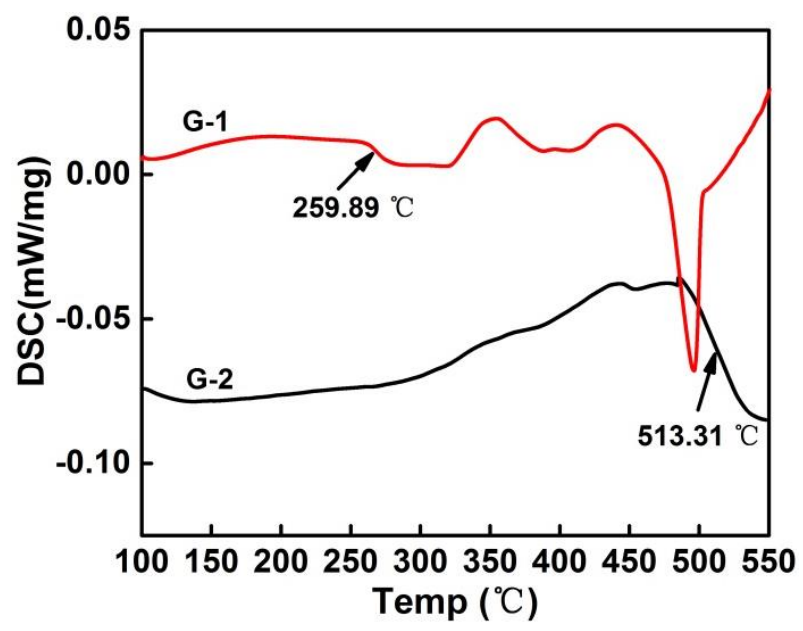

Figure 6. DSC curve of the as-prepared glass frit.
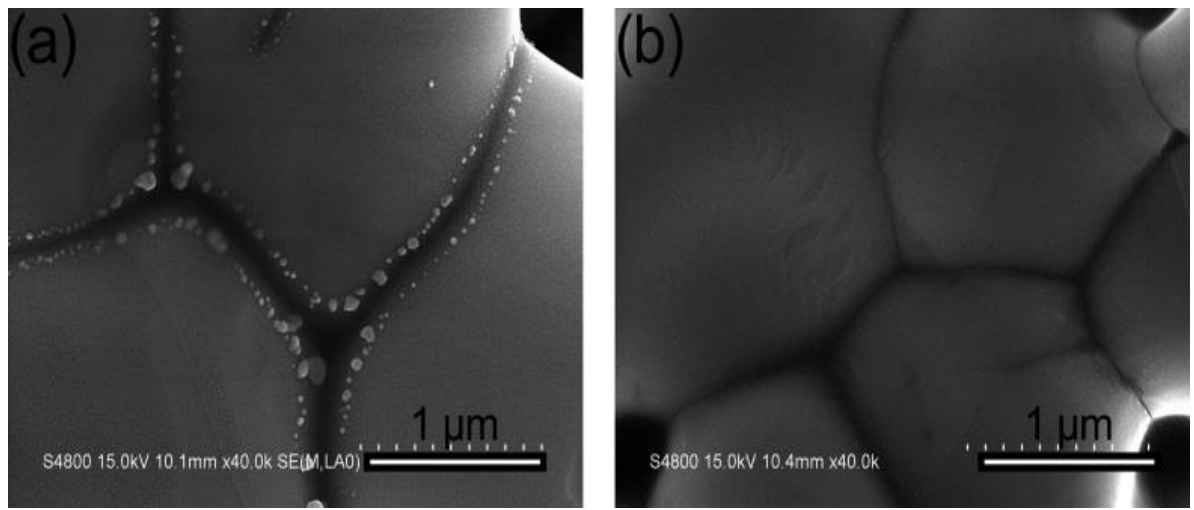

Figure 7. Surface morphology of sintered Ag electrode. (a) P-1 paste; (b) P-2 paste. 


\section{Conclusions}

The interfacial contact resistance of $\mathrm{Ag} / \mathrm{Al}$ electrodes and the relationship between the glass frit in $\mathrm{Ag}$ paste and the $\mathrm{Ag} / \mathrm{Al}$ contact were examined. By investigating the interface morphology of $\mathrm{Ag}$ and $\mathrm{Al}$ electrodes and the interaction between glass frit and $\mathrm{Al}$, the results showed that low $\mathrm{T}_{\mathrm{g}}$ glass with a strong reaction with $\mathrm{Al}$ could cause a non-conductive glass layer at the $\mathrm{Ag} / \mathrm{Al}$ contact interface and a high $\mathrm{Ag} / \mathrm{Al}$ contact resistance. However, when a high- $\mathrm{T}_{\mathrm{g}}$ glass frit which has no reaction with $\mathrm{Al}$ was used, the current transmission between $\mathrm{Ag}$ and $\mathrm{Al}$ was easier and eventually resulted in a low $\mathrm{Ag} / \mathrm{Al}$ contact resistance. Therefore, in order to obtain a lower contact resistance, the composition of glass frit in Ag paste should be reasonably designed and controlled.

Supplementary Materials: The following are available online at http:/ /www.mdpi.com/2076-3417/9/5/891/s1, Figure S1: Photographs showing the $\mathrm{SiN}_{\mathrm{x}} / \mathrm{Al}_{2} \mathrm{O}_{3}$ passivation layer after the glass frit was coated on $\mathrm{SiN}_{\mathrm{x}} / \mathrm{Al}_{2} \mathrm{O}_{3}$ passivated mono-crystalline wafers and fried in an open furnace at $700{ }^{\circ} \mathrm{C}$ for $10 \mathrm{~s}$, and then removed by $30 \%$ $\mathrm{HNO}_{3}$ for $3 \mathrm{~h}$. (a) G-1 glass frit; (b) G-2 glass frit, Figure S2: The line resistivity pattern of the sintered Ag electrode, Figure S3: The line resistivity of the sintered Ag electrode.

Author Contributions: Investigation, J.Z. and H.L.; Supervision, S.X. and Y.Y.; Resources, X.Y., H.L. and C.L.; Writing-Original Draft Preparation, J.Z.; Writing—Review \& Editing, H.T.

Funding: This study was partly supported by the Shanghai Science and Technology Committee Project [Number 17DZ1201102]. We also acknowledge the support from the National Natural Science Foundation of China [Grant Number 51202272] and Shanghai Municipal Science and Technology Commission [Grant Number 16DZ2260600].

Conflicts of Interest: The authors declare no conflict of interest.

\section{References}

1. Blakers, A.W.; Wang, A.; Milne, A.M.; Zhao, J.; Green, M.A. 22.8\% efficient silicon solar cell. Appl. Phys. Lett. 1998, 55, 1363-1365. [CrossRef]

2. Urban, T.; Mette, A.; Heitmann, J. Influence of silver-aluminium alloy at solar cell rear side on series resistance and open circuit voltage. Energy Procedia 2016, 92, 236-241. [CrossRef]

3. Urban, T.; Heimann, M.; Schmid, A.; Mette, A.; Heitmann, J. Analysis of ohmic losses due to solder and pressure interconnection and related interface resistances for solar cells. Energy Procedia 2015, 77, 420-427. [CrossRef]

4. Qin, J.; Zhang, W.; Bai, S.; Liu, Z. Effect of Pb-Te-O glasses on Ag thick-film contact in crystalline silicon solar cells. Sol. Energy Mater. Sol. Cells 2016, 144, 256-263. [CrossRef]

5. Tai, Y.; Zheng, G.; Wang, H.; Wang, H.; Bai, J. Effect of glass frit in Ag paste on the electrical properties of front-side Ag contacts for crystalline-silicon solar cells. RSC Adv. 2015, 5, 92515-92521. [CrossRef]

6. Kumar, P.; Pfeffer, M.; Willsch, B.; Eibl, O. Contact formation of front side metallization in p-type, single crystalline Si solar cells: Microstructure, temperature dependent series resistance and percolation model. Sol. Energy Mater. Sol. Cells 2016, 145, 358-367. [CrossRef]

7. Fields, J.D.; Ahmad, M.I.; Pool, V.L.; Yu, J.; Van Campen, D.G.; Parilla, P.A.; Toney, M.F.; van Hest, M.F. The formation mechanism for printed silver-contacts for silicon solar cells. Nat. Commun. 2016, 7, 11143. [CrossRef] [PubMed]

8. Kumar, P.; Aabdin, Z.; Pfeffer, M.; Eibl, O. High-efficiency, single-crystalline, p- and n-type Si solar cells: Microstructure and chemical analysis of the glass layer. Sol. Energy Mater. Sol. Cells 2018, 178, $52-64$. [CrossRef]

9. Finkenstadt, D.; Johnson, D.D. Analysis of nonequilibrium hcp precipitate growth in fcc matrices: Application to Al-Ag. Mater. Sci. Eng. A 2009, 525, 174-180. [CrossRef]

10. Fang, M.; Taher, M.; Kryshtal, O.; Kruk, A.; Czyrskafilemonowicz, A.; Ottosson, M.; Andersson, A.M.; Wiklund, U.; Jansson, U. Combinatorial study of gradient Ag-Al thin films: Microstructure, phase formation, mechanical and electrical properties. ACS Appl. Mater. Interfaces 2016, 8, 30635-30643.

11. Zhang, J.; Yuan, X.; Tong, H.; Yang, Y.; Zhao, H.; Li, H. Effect of glass phase and temperature on contact resistance between Ag and Al electrodes. Mater. Res. Express 2018, 6, 035202. [CrossRef] 
12. Hilali, M.M.; Sridharan, S.; Khadilkar, C.; Shaikh, A.; Rohatgi, A.; Kim, S. Effect of glass frit chemistry on the physical and electrical properties of thick-film Ag contacts for silicon solar cells. J. Electron. Mater. 2006, 35, 2041-2047. [CrossRef]

13. Wang, H.; Ma, S.; Ma, Q.; Cheng, X.; Wang, H.; Bai, J. Effect of composition of front-electrode-paste glass on electrical performance of multicrystalline silicon solar cells. J. Mater. Sci. Mater. Electron. 2017, 28, 6936-6949. [CrossRef]

14. Zheng, G.; Tai, Y.; Wang, H.; Bai, J. Effect of the Pb-Te-B-O system glass frits in the front contact paste on the conversion efficiency of crystalline silicon solar cells. J. Mater. Sci. Mater. Electron. 2014, 25, 3779-3786. [CrossRef] 